\title{
IDENTIFIKASI JAMUR DAN BAKTERI PADA BEBERAPA PENGGUNAAN LAHAN DI KOTA SAMARINDA
}

\author{
(Identification of Fungi and Bacteria in Several Land Use in Samarinda City)
}

\author{
Zainudin $^{1}$ dan Roro Kesumaningwati ${ }^{2}$ \\ ${ }^{1}$ Fakultas Pertanian Universitas Widyagama Mahakam Samarinda \\ ${ }^{2}$ Fakultas Pertanian Universitas Mulawarman Samarinda \\ Penulis Koresponden : rorokesuma99@gmail.com
}

Article Submitted: 26-02-2021

Article Accepted: 12-04-2021

\begin{abstract}
Land-use change indirectly affects soil biological fertility. Changes in forest land use into land use have an impact on the impact of soil organic matter which will affect the microorganism population. Microorganisms and carbon, in general, are more sensitive to changes in land use. Microorganism biomass changes more rapidly after land-use changes. The research objective was to detect soil fungi and bacteria on different land uses, namely mixed forest, seasonal crop farming, and former coal mining land. The research stages included: soil surveys for sampling and bacterial and fungal surveys conducted in the laboratory. The research method for observing soil properties is a random sampling of soil at each land use, namely seasonal cropland, mixed garden land, secondary forest, and former coal mining land. Composite soil samples were taken from 5 subsamples to obtain one composite sample for each different land use and soil depth. The results showed that Mucor and Trichoderma with the highest total population of $3.2 \times 104 \mathrm{Cfu} / \mathrm{gr}$ were found in seasonal crops with a depth of 30-60 cm. The bacteria found were Azotobacteraceae with the highest total population of $1.5 \mathrm{x} 105 \mathrm{Cfu} / \mathrm{gr}$ found in seasonal crops.
\end{abstract}

Keywords: land use, soil microorganisms, microorganism biomass

\section{PENDAHULUAN}

Kesehatan tanah merupakan faktor penting dalam budidaya pertanian. Tanah yang sehat salah satunya ditunjukkan dengan banyaknya populasi mikroorganisme di dalamnya. Mikroorganisme di dalam tanah memiliki peranan terhadap kesuburan tanah baik kesuburan fisik, kimia, dan biologi tanah. Mikroorganisme tanah berperan dalam siklus hara tanah sehingga merupakan komponen penting dalam suatu agroekosistem. Di alam terdapat berbagai jenis mikroorganisme, seperti jamur, dan bakteri. Berbagai jenis mikroorganisme tersebut dapat ditemui di udara bebas, hidup di area daun atau dalam jaringan tanaman, dan hidup di dalam tanah yang sebagian bersimbiosis dengan perakaran tanaman. Di dalam tanah, mikroorganisme terdapat dalam jumlah yang berbeda. Keragaman jumlah mikroorganism terjadi pada penggunaan lahan yang berbeda. Penggunaan lahan seperti konversi hutan primer menjadi hutan sekunder, lahan pertanian dan menjadi areal penambangan merupakan salah satu faktor yang dapat menurunkan populasi mikroorganisme. Penggunaan lahan juga mempengaruhi jenis vegetasi yang ada diatas tanah. Vegetasi dan mikroorganisme tanah memiliki hubungan yang erat oleh karena itu penting sekali 
untuk melakukan identifikasi populasi mikrorganisme tanah seperti jamur dan bakteri pada beberapa penggunaan lahan pada kedalaman tanah yang berbeda sehingga dapat diberoleh gambaran kondisi Kesehatan tanah.

\section{METODE PENELITIAN}

Penelitian dilakukan tahun 2020. Pengambilan sampel tanah dilakukan di Kelurahan Mugirejo, Kecamatan Sungai Pinang. Laboratorium yang digunakan untuk analisis jamur dan bakteri adalah Laboratorium HPT Faperta Universitas Mulawarman.

Tabel 1. Alat penelitian

\begin{tabular}{lll}
\hline No & \multicolumn{1}{c}{ Tahapan Penelitian } & \multicolumn{1}{c}{ Peralatan } \\
\hline 1. & Pembuatan potato glukos agar & Kompor, erlenmeyer, autoklaf \\
2. & Pembuatan nutrient agar & Erlenmeyer, autoklaf \\
3. & Pengamatan jamur & Tabung reaksi, mikroskop \\
4. & Pengamatan bakteri & Tissue, jarum ose, mikroskop \\
\hline
\end{tabular}

Tabel 2. Bahan penelitian

\begin{tabular}{lll}
\hline No. & \multicolumn{1}{c}{ Tahapan penelitian } & \multicolumn{1}{c}{ Bahan } \\
\hline 1. & Pembuatan potato glukos agar & Kentang, air, agar-agar, gula \\
2. & Pembuatan nutrient agar & Daging, air, agar-agar, gula, pepton, \\
3. & Pengamatan jamur & Sampel tanah, aie destilasi, methilene blue \\
4. & Pengamatan bakteri & Reagen pewarna ungu kristal, mardan iodium, etanol \\
\hline
\end{tabular}

\section{Pengambilan sampel tanah}

Sampel tanah diambil dengan metode acak pada penggunaan lahan yang berbeda, yaitu tanaman semusim, kebun campuran, hutan sekunder, dan bekas tambang batubara. Sampel tanah diambil secara komposit dari 5 sub sampel. Kedalaman tanah pada pengambilan sampel adalah $0-30 \mathrm{~cm}$ dan $30-60 \mathrm{~cm}$.

\section{Pembuatan Media}

Media sangat diperlukan untuk proses pembiakan bakteri dan jamur. Pembuatan media sebagai berikut:

1. Media Potato Glukos Agar

Cara pembuatan : kentang dikupas dan cuci, lalu dipotong kecil dan kemudian direbus dengan air sampai mencapai volume $1000 \mathrm{ml}$. Pisahkan kentang dan cairan kemudian ambil cairannya. Masukkan cairan ke erlenmeyer dan tambahkan 20 gram bubuk agar serta 20 gram gula, lalu aduk sampai merata. Tutup tabung erlenmeyer dengan alumunium foil dan selotip lalu sterilisasi dengan autoklaf. Angkat bahan dan didinginkan.

2. Nutrien Agar

Cara pembuatan : daging dicuci, lalu dipotong kecil, rebus sampai volume mencapai $1000 \mathrm{ml}$. Pisahkan daging dan ekstrak kemudian ambil ekstraknya. Masukkan ekstrak ke erlenmeyer lalu tambahkan 20 gram serbuk agar serta 20 gram gula. Aduk sampai merata. Tutup erlenmeyer dengan alumunium foil dan selotip. Sterilkan dengan autoklaf. Angkat dan dinginkan. Siap digunakan.

\section{Pengamatan laboratorium}

\section{Jamur}

Untuk mengisolasi jamur tanah dapat dilakukan dengan metode pengenceraan, langakah kerja metode pengenceran menurut sebagai berikut. 
a. Menimbang seberat 3 gram sampel tanah.

b. Memasukkan hasil timbangan kedalam tabung reaksi yang berisi $10 \mathrm{ml}$ air destisalasi.

c. Kemudian larutan diratakan dengan cara dikocok sampai menyatu.

d. Mengambil $1 \mathrm{ml}$ larutan kemudian dilarutkan kembali ke dalam $9 \mathrm{ml}$ air destilasi.

e. Langkah ini diulangi sampai 3 kali.

f. Hasil dari pengenceran kemudian di inokulasikan kedalam media PDA.

g. Melakukan pengamatan pada saat koloni jamur mulai terlihat.

Untuk mengisolasi tanaman yaitu dengan cara mengambil bagian yang bergejala terserang jamur kemudian dibiakkan kedalam media PDA. Setelah diinkubasi kurang lebih 3-4 hari diamati spora yang tumbuh, kemudian diambil dengan menggunakan jarum ent untuk diletakkan pada kaca preparat yang telah diberikan cairan methilene blue untuk diamati dibawah mikroskop berdasarkan ciri morfologinya (Alexopoulos, et al., 1979).

2. Bakteri

Untuk metode pengenceran bakteri dapat dilakukan seperti pengenceran pada jamur, hanya saja media PDA digantikan dengan media NA. Identifikasi penyakit yang diduga akibat bakteri tidak dilakukan secara mendalam, yaitu hanya melakukan isolasi bakteri untuk melihat ciri koloni bakteri. Adapun cara mengisolasi bakteri dari bagian tanaman yang terinfeksi, yaitu dengan menyiapkan media NA pada cawan pentri. Selanjutnya ambil bagian tanaman yang bergejala untuk dibiakkan didalam cawan petri. Selanjutnya diinkubasi selama bakteri yang tumbuh.

Pengamatan bakteri

a. Penyiapan preparat :

1. Buatlah lapisan tipis (olesan) bakteri pada kaca obyek, dengan menggunakan jarum ose.

2. Kering udarakan lapisan tersebut, dan fiksasi dengan panas dengan cara melewatkan diatas nyala lampu bunsen untuk beberapa saat.

3. Genangi olesan kering udara yang telah difiksasi dengan panas selama 1 menit didalam reagen pewarna ungu kristal (campuran larutan A dan B).

4. Bilaslah olesan dengan air keran yang mengalir perlkahan dan tidak langsung selama 2 detik, kemudian keringkan dengan menekankan kertas tissue keatasnya.

5. Genangi olesan didalam mordan iodium (larutan C) selama 1 menit.

6. Bilaslah olesan dengan air keran yang mengalir perlahan dan tidak langsung selama 2 detik, kemudian tekan dengan kertas tissue sampai kering.

7. Genangi olesan didalam etanol $95 \%$ (vol/vol) (Larutan D) selama 30 detik sambil menggoyang-goyangkannya, dan kemudian tekan dengan kertas tissue sampai kering.

8. Genangi olesan selama 10 detik didalam pewarna tandingan (Larutan E).

9. Bilaslah olesan dengan aliran air keran yang mengalir perlahan dan tidak langsung sampai tidak tampak lagi adanya warna didalam air bilasan, dan kemudian tekan dengan kertas tissue samapi kering.

10. Preparat siap diamati dibawah mikroskop. Catat dan gambar masingmasing hasil preparat yang diamati :

- Warna/gram bakterinya

- bentuk bakterinya.

\section{HASIL DAN PEMBAHASAN}

\section{Pengamatan jamur}

Kesuburan tanah secara biologi dipengaruhi oleh populasi mikroorganisme. Populasi mikroorganisme berkaitan dengan ketersediaan makanan, ketersediaan air serta kesesuaian lingkungan hidup bagi mikroorganisme. Populasi mikroorganisme berkaitan dengan lingkungan hidup mikroorganisme serta kandungan bahan organik tanah. 
Menurut Sahara, N. Wardah, dan Rahmawati. (2019), kelimpahan mikroorganisme sangat ditentukan oleh kadar bahan organik tanah. Faktor lain yang juga menentukan adalah $\mathrm{pH}$ serta kelembaban tanah. Faktor yang mempengaruhi adalah vegetasi dan suhu.

Tabel 3. Hasil analisis Jamur pada beberapa penggunaan lahan

\begin{tabular}{clcl}
\hline No & \multicolumn{1}{c}{ Penggunaan lahan } & $\begin{array}{c}\text { Total Populasi } \\
(\mathrm{Cfu} / \mathrm{gr})\end{array}$ & \multicolumn{1}{c}{ Identifikasi jamur } \\
\hline 1 & Tanah pasca tambang $(0-30 \mathrm{~cm})$ & $1,6 \times 10^{4}$ & Mucor, Trichoderma \\
2 & Tanah pasca tambang $(30-60 \mathrm{~cm})$ & $2,4 \times 10^{4}$ & Mucor, Trichoderma \\
3 & Tanaman semusim $(0-30 \mathrm{~cm})$ & $3,1 \times 10^{4}$ & Mucor, Trichoderma \\
4 & Tanaman semusim $(30-60 \mathrm{~cm})$ & $3,2 \times 10^{4}$ & Mucor, Trichoderma \\
5 & Kebun campuran $(0-30 \mathrm{~cm})$ & $1,5 \times 10^{4}$ & Mucor, Trichoderma \\
6 & Kebun campuran $(30-60 \mathrm{~cm})$ & $2,4 \times 10^{4}$ & Mucor, Trichoderma \\
7 & Hutan sekunder $(0-30 \mathrm{~cm})$ & $1,2 \times 10^{4}$ & Mucor, Trichoderma \\
8 & Hutan sekunder $(30-60 \mathrm{~cm})$ & $1,8 \times 10^{4}$ & Mucor,Trichoderma \\
\hline
\end{tabular}

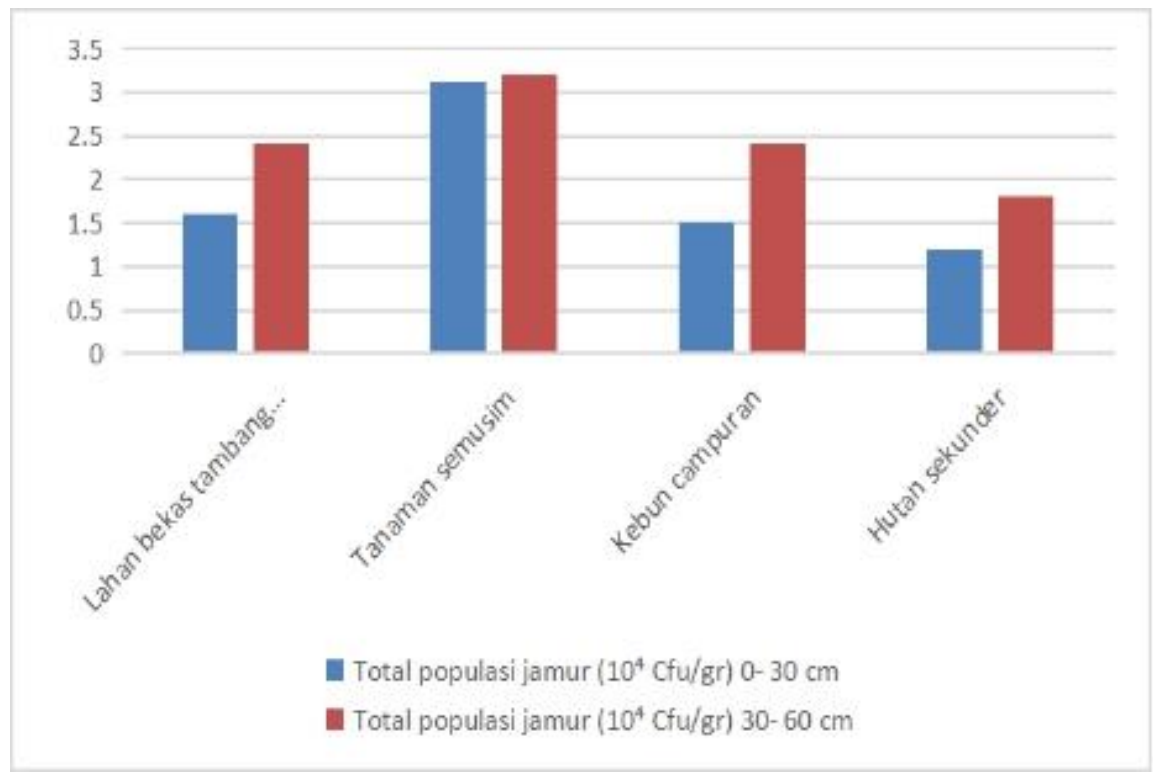

Gambar 1. Total populasi jamur pada beberapa penggunaan lahan

Berdasarkan tabel 3, dan Gambar 1 dapat dilihat bahwa populasi jamur lebih rendah pada kedalaman tanah 0-30 $\mathrm{cm}$ dan populasi jamur terendah terdapat pada hutan sekunder dengan nilai $1,2 \times 10^{4} \mathrm{Cfu} / \mathrm{gr}$. Total populasi jamur tertinggi adalah $3,2 \times 10^{4} \mathrm{Cfu} / \mathrm{gr}$ yang terdapat pada lahan tanaman semusim kedalaman $30-60 \mathrm{~cm}$. Penurunan populasi jamur diduga berkaitan dengan menurunnya tingkat tutupan lahan. Widyati, E. (2019), menegaskan bahwa perubahan fungsi lahan akan merubah komposisi vegetasi, hal ini akan mengubah kualitas substrat dan ketersediaan nutrien bagi jamur tanah, sehingga akan mengubah struktur komunitas jamur tersebut. Hutan sekunder yang 
menjadi lokasi penelitian memiliki tutupan lahan yang tidak rapat sehingga matahari secara langsung dapat sampai pada permukaan tanah yang secara langsung mempengaruhi suhu tanah.

Penurunan komunitas mikroorganisme juga diakibatkan oleh pengolahan tanah yang terjadi pada lahan yang diolah seperti lahan tanaman semusim, kebun campuran, maupun lahan bekas tambang batubara, yang biasa terdapat pada lapisan $0-30 \mathrm{~cm}$. Pengolahan tanah dapat menghilangkan residu Bahan Organik Tanah (BOT). Pengolahan tanah juga mengakibatkan tanah memiliki kelembaban, kandungan amonium dan nitrat serta emisi
$\mathrm{N}_{2} \mathrm{O}$ berbeda yang akan menyeleksi populasi komunitas mikroorganisme.

Dijelaskan oleh Kesumaningwati, dkk (2018), keanekaragaman mikroorganisme dapat berubah akibat penggunaan pestisida seperti pada lahan tanaman semusim, dan perubahan ini berdampak terhadap mikroorganisme tanah.

Jamur Mucor dan Trichoderma ditemukan pada keempat jenis penggunaan lahan pada kedalaman yang berbeda. Jamur Mucor, dicirikan dengan warna isolat putih, bagian tepi rata, dan tektsur seperti kapas. Jamur memiliki hifa tidak bersekat, dan menghasilkan sporangium dengan bentuk bulat pada ujung hifa (Sulistiyono, F. D., dan S. Mahyuni. 2019).

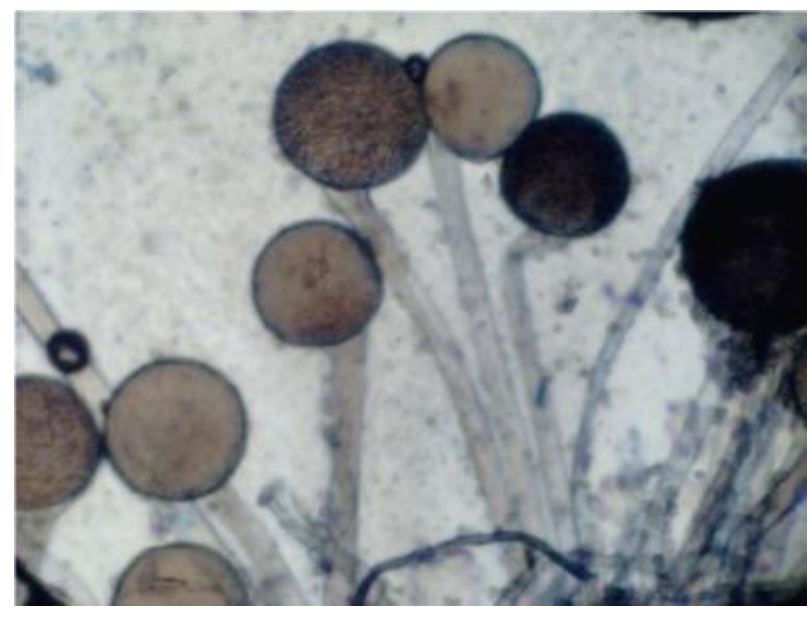

Gambar 2. Jamur Mucor

Genus Mucor mampu menghasilkan protease, yakni enzim yang berperan dalam siklus nitrogen di dalam tanah (Ristiari, 2018). Beberapa spesies Mucor bisa memproduksi enzim proteolitik dan metabolit sekunder. Mucor menunjukkan produksi protease yang tinggi dengan menggunakan glukosa sebagai substrat (Thuong T. T. Nguyen, 2020).
Karim, A., dkk, (2020), Trichoderma dicirikan dengan permukaan yang datar dengan bentuk bulat. Trichoderma merupakan koloni berwarna putih kombinasi hijau tua dalam bentuk lingkaran. Menurut Ristiari (2018), Trichoderma spp. bermanfaat karena merupakan jamur saprofit yang menyerang jamur patogen dalam tanah 


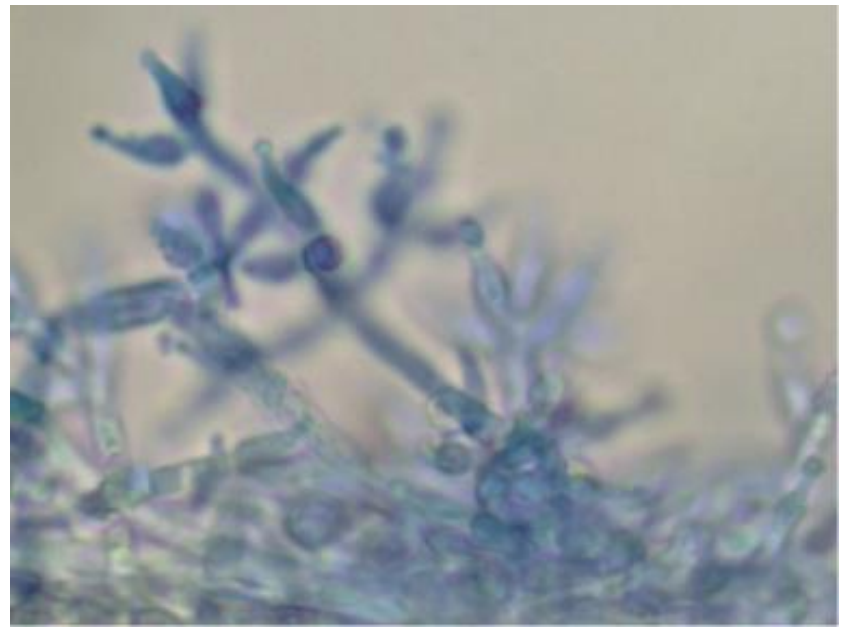

Gambar 3. Jamur Trichoderma

. Ditambahkan oleh Frac, M., (2018) bahwa penyakit tanaman dapat dikendalikan oleh beberapa jamur antagonis seperti Trichoderma sp. Spesies Trichoderma sering digunakan dalam biokontrol dan dikenal sebagai biostimulan untuk tanaman hortikultura. Trichoderma juga termasuk pendegradasi selulosa dan fosfat. Trichoderma merupakan mikroba yang mampu menghasilkan ketiga komponen selulase, diantaranya selobiohidrolase, endoglukanase, dan p-glukosidase, sehingga genus ini sering disebut selulolitik sejati (Ristiari, 2018). Trichoderma juga merupakan salah satu jamur yang mampu mengurai serasah dengan kandungan selulosa dan lignin (Elfiati, D., et al., 2019).

\section{Analisis Bakteri}

Tabel 4. Hasil analisis Bakteri pada beberapa penggunaan lahan

\begin{tabular}{|c|c|c|c|}
\hline No & Penggunaan lahan & $\begin{array}{l}\text { Total Poppulasi } \\
\quad \text { (Cfu/gr) }\end{array}$ & Identifikasi jamur \\
\hline 1 & Tanah pasca tambang $(0-30 \mathrm{~cm})$ & $1,3 \times 10^{5}$ & Basil, gram (-) : Azotobacteraceae \\
\hline 2 & Tanah pasca tambang $(30-60 \mathrm{~cm})$ & $1,2 \times 10^{5}$ & Basil, gram (-) : Azotobacteraceae \\
\hline 3 & Tanaman semusim $(0-30 \mathrm{~cm})$ & $8,7 \times 10^{4}$ & Basil, gram (-) : Azotobacteraceae \\
\hline 4 & Tanaman semusim $(30-60 \mathrm{~cm})$ & $1,5 \times 10^{5}$ & $\begin{array}{l}\text { Basil, gram (-) : Azotobacteraceae } \\
\text { Kokus, gram (-) : Azotobacteraceae }\end{array}$ \\
\hline 5 & Kebun campuran $(0-30 \mathrm{~cm})$ & $9,8 \times 10^{4}$ & $\begin{array}{l}\text { Basil, gram (-) : Azotobacteraceae } \\
\text { Kokus, gram (-) : Azotobacteraceae }\end{array}$ \\
\hline 6 & Kebun campuran $(30-60 \mathrm{~cm})$ & $1,1 \times 10^{5}$ & Kokus, gram (-) : Azotobacteraceae \\
\hline 7 & Hutan sekunder $(0-30 \mathrm{~cm})$ & $5,6 \times 10^{4}$ & $\begin{array}{l}\text { Basil, gram (-) : Azotobacteraceae } \\
\text { Kokus, gram (-) : Azotobacteraceae }\end{array}$ \\
\hline 8 & Hutan sekunder $(30-60 \mathrm{~cm})$ & $1,5 \times 10^{5}$ & $\begin{array}{l}\text { Basil, gram (-) : Azotobacteraceae } \\
\text { Kokus, gram (-) : Azotobacteraceae }\end{array}$ \\
\hline
\end{tabular}




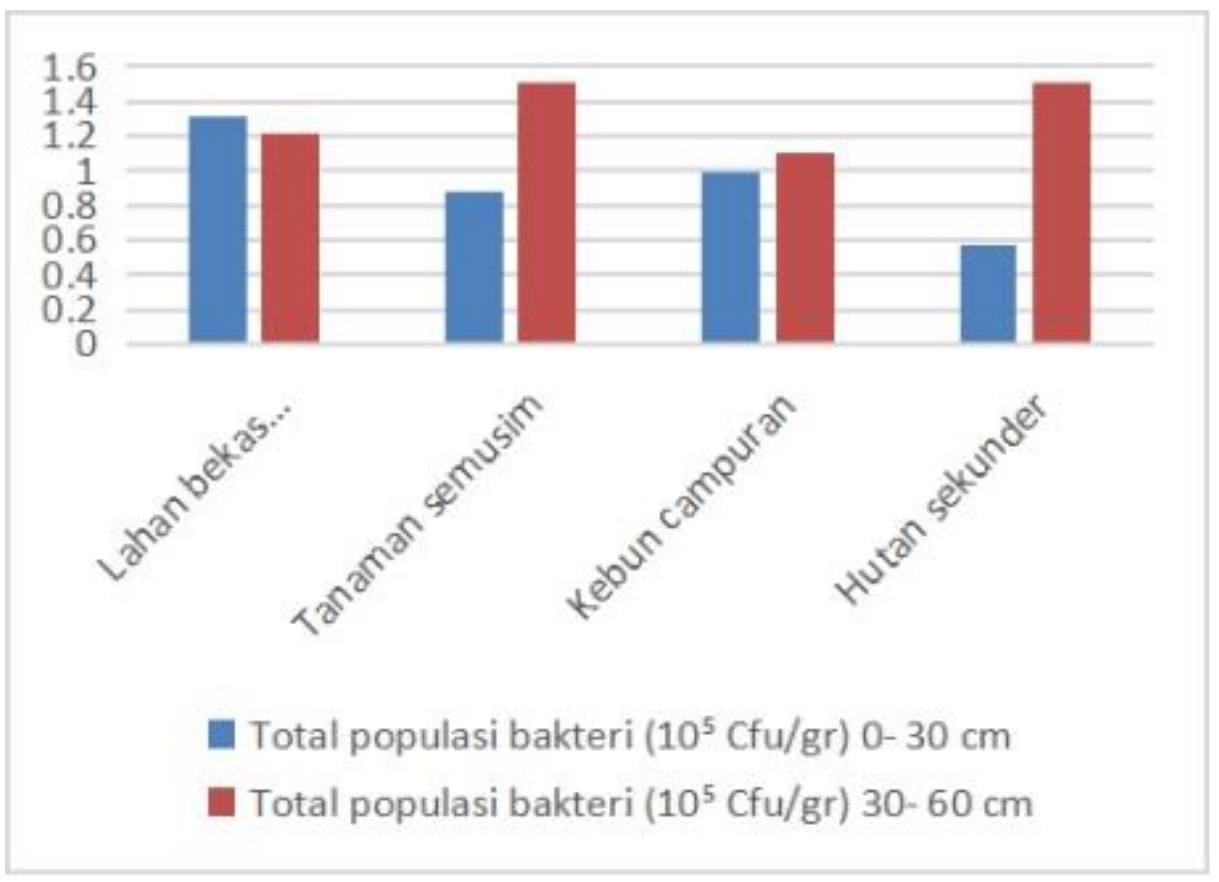

Gambar 4. Grafik 2. Total populasi bakteri pada beberapa penggunaan lahan

Partikel tanah terikat oleh bahan kimia organik termasuk senyawa yang dihasilkan oleh bakteri tanah. Biokimia yang dihasilkan oleh bakteri tanah diantaranya polisakarida yang berdampak terhadap pengikatan partikel tanah. Mineralisasi mikroorganisme tanah pada bahan organik juga dapat mempengaruhi struktur tanah, dan meningkatkan jumlah eksudat akar serta mempengaruhi struktur tanah dan meningkatkan populasi mikroba. (Yadav, N. V., et al. 2017)

Penelitian Widawati, dkk (2005), Bakteri lebih banyak populasinya di dalam tanah dibandingkan dengan mikroorganisme lain, hal ini seperti ditunjukkan pada tabel 4 dan grafik 2 dimana total populasi bakteri lebih tinggi dibandingkan dengan total populasi jamur pada tabel 1 dan grafik 1 . Ditambahkan oleh Asadu, et al, (2015) bahwa tanah pada lahan penelitian mengandung lebih banyak bakteri daripada jamur karena bakteri kurang rentan terhadap perubahan kondisi tanah dan lingkungan, tidak seperti jamur yang dibatasi oleh $\mathrm{pH}$ tanah, unsur hara dan kondisi lingkungan yang berat.
Pada lokasi penelitian, ditemukan genus Azotobacteraceae. Bakteri Azotobacteraceae adalah gram negatif, aerobik, heterotrofik, dan merupakan bakteri pengikat nitrogen berbentuk batang, biasa terdapat di tanah basa dan netral serta merupakan bakteri yang hidup bebas. Azotobacteraceae merupakan bakteri pemacu pertumbuhan tanaman yang dapat menghasilkan sitokinin atau giberelin atau keduanya untuk meningkatan pertumbuhan tanaman (Yadav, N. V., et al. 2017).

Ditambahkan oleh Kesumaningwati, dkk (2018) bahwa bakteri Azotobacter memiliki manfaat bagi tanah karena dapat mengurangi logam berat terutama pada tanah tercemar. Azotobacteraceae juga bermanfaat pada penyediaan unsur hara nitrogen pada tanah. Keragaman mikroorganisme tanah juga dapat dipengaruhi oleh jenis penggunaan lahan. Hasil penelitian Fitriatin (2006) menunjukkan bahwa aktivitas enzim fosfatase pada rhizosfir lebih besar dibadingkan di daerah nonrhizosfir. Kondisi ini menunjukkan adanya aktivitas mikroorganisme di daerah rhizosfir yang 
lebih banyak dan memberikan kontribusi yang positif terhadap tanaman.

Berdasarkan tabel 2 diperoleh total populasi bakteri yang tertinggi adalah pada penggunaan lahan tanaman semusim dan hutan sekunder dengan kedalaman $0-30 \mathrm{~cm}$ dengan jumlah populasi bakteri yaitu 1,5 x $10^{5} \mathrm{Cfu} / \mathrm{gr}$. Ditambahkan oleh (Solihin, M. A dan B. N. Fitriatin, 2017), Penggunaan lahan berupa tanaman semusim dapat mendorong keragaman vegetasi, disamping itu, teknologi budidaya tanaman semusim berupa pemupukan baik anorganik maupun organik ikut memacu pertumbuhan mikroorganisme tanah. Tingginya populasi bakteri pada lahan tanaman semusim juga dipengaruhi oleh pengolahan tanah. Pengolahan tanah akan memperbaiki struktur, tekstur dan aerasi dari tanah (Permana, dkk., 2017).

Tingginya populasi bakteri pada hutan sekunder disebabkan oleh vegetasi hutan sekunder yang memiliki karagaman yang lebih tinggi dibandingkan dengan penggunaan lahan lainnya, serta karakteristik lahan hutan sekunder yang memiliki bahan organik serta kelembaban yang lebih tinggi. Kondisi ini mendukung untuk pertumbuhan mikroorganisme yang optimal. Jumlah mikroorganisme yang berbeda pada penggunaan lahan menunjukkan tingkat aktivitasnya di dalam tanah. Semakin tinggi tingkat aktivitas mikroorganisme, maka perannya dalam proses biokimia dalam tanah menjadi lebih besar sehingga penggunaan pupuk anorganik dapat dikurangi (Solihin, M. A dan B. N. Fitriatin, 2017).

Berdasarkan hasil analisis pada tabel 2 diperoleh bahwa keragaman dan total populasi bakteri pada lahan bekas tambang batubara lebih kecil dibandingkan dengan penggunaan lahan lainnya. Dijelaskan oleh Zainudin, dan Kesumaningwati, (2020) bahwa penambahan bahan organik tidak memberi pengaruh pada populasi Azotobacteraceae pada tanah bekas tambang, karena tanah bekas tambang mengandung $\mathrm{N}$ rendah sehingga mengakibatkan $\mathrm{C} / \mathrm{N}$ tinggi, hal ini menyebabkan aktivitas mikroba perlu waktu lebih lama untuk mendekomposisi bahan organik.

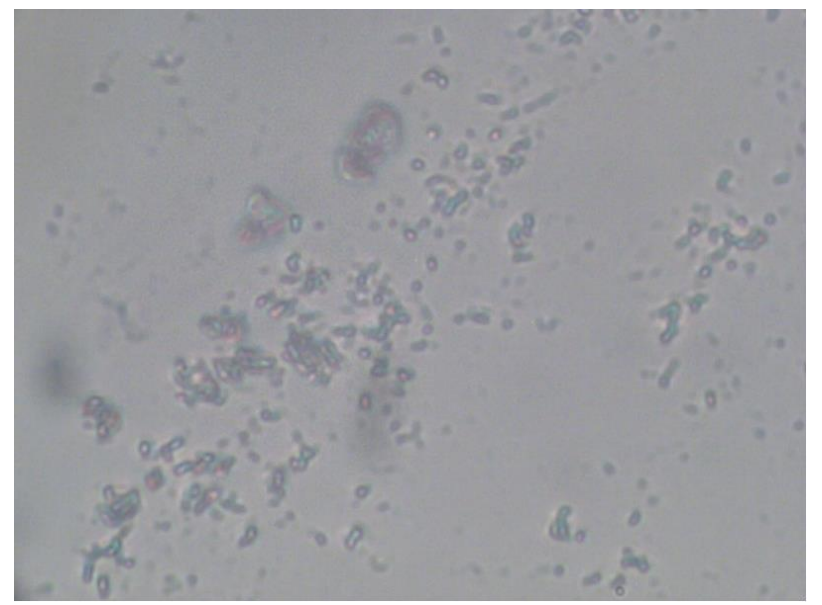

Gambar 5. Bakteri Azotobacteraceae 


\section{KESIMPULAN}

Berdasarkan hasil penelitian diperoleh bahwa jamur yang ditemukan adalah Mucor dan Trichoderma dengan total populasi jamur tertinggi adalah $3,2 \times 10^{4}$ Cfu/gr yang terdapat pada lahan tanaman semusim kedalaman $30-60 \mathrm{~cm}$. Bakteri yang ditemukan adalah dari Genus Azotobacteraceae dengan total populasi tertinggi adalah $1,5 \times 10^{5} \mathrm{Cfu} / \mathrm{gr}$ yang terdapat pada lahan tanaman semusim dan hutan sekunder kedalaman $30-60 \mathrm{~cm}$.

\section{UCAPAN TERIMA KASIH}

Terima Kasih kepada Univeritas Widyagama Mahakam Samarinda atas bantuan pendanaan hibah tahun 2021

\section{DAFTAR PUSTAKA}

Asadu C. L. A., Nwafor I. A., and Chibuike G. U. 2015. Contributions of Microorganisms to Soil Fertility in Adjacent Forest, Fallow and Cultivated Land Use Types in Nsukka, Nigeria. International Journal of Agriculture and Forestry 2015, 5(3): 199-204 DOI: 10.5923/j.ijaf.20150503.04

Alexopoulos, C. J., and Mims, C. W. 1979. Introductory mycology. Library of Congres Cataloging in Publication Data, United States of America

Elfiati, D., et al. 2019. Isolation and identification of decomposer fungi from Macaranga indica and Hibiscus macrophyllus leaf litter from restoration area of Gunung Leuser National Park. IOP Conf. Ser.: Earth Environ. Sci, 1-6

Frąc M, Hannula SE, Bełka $\mathrm{M}$ and Jędryczka M. 2018. Fungal Biodiversity and Their Role in Soil Health. Front. Microbiol. 9:707. doi: 10.3389/fmicb.2018.00707
Karim, A., Rahmiati, dan I. Fauziah. 2020. Isolasi Dan Uji Antagonis Trichoderma Terhadap Fusarium Oxysporum Secara In Vitro. Jurnal Biosains Vol. 6 No. 1. DOI : https://doi.org/10.24114/jbio.v6i1.16 $\underline{839}$

Kesumaningwati, R., dan N. P. Palupi. 2018. Peranan Kompos Sampah Pasar Dengan Bioaktivator Mol Dan Trichoderma Terhadap Peningkatan Sifat Biologi Tanah Bekas Tambang Batubara. J. Agrifarm : Vol. 7 No. 2, 44-49

Khulillah, I , A. L. Abadi, dan L. Q. Aini. 2019. Pengaruh Fungisida Terhadap Keanekaragaman Bakteri Tanah Di Kota Batu. Jurnal Tanah dan Sumberdaya Lahan Vol 6 No 2 : 1209-1218

Lambui, O dan M. Jannah.2017. Isolation and Identification of Soil Bacteria in Forest Around Lake Kalimpa'a, Lore Lindu National Park Area, Central Sulawesi. Online Journal of Natural Science Vol 6(1):73-82

Lavahun, E.M.F. 1995. Depth and Time Function of Microbial Biomass in Ploughed and Grassland Typudalfs of Lower Saxony, Germany. Thesis. The Faculty of Agriculture. GeorgeAugust-University Goettingen

Pasaribu, P., H. Nirwanto, dan W. S. Harijani. 2019. Keanekaragaman Mikroorganisme Rhizosfer Dalam Menekan Tingkat Serangan Penyakit Bulai Pada Tanaman Jagung Di Kabupaten Jombang. Plumula Volume 7 No. 1: hal 54-55

Paul, E.A. and F.E. Clark. 1989. Soil Microbiology and Biochemistry. Academic Press, Inc. London 
Permana., I. W. D. Atmaja, dan I. W. Narka. 2017. Pengaruh Sistem Pengolahan Tanah dan Penggunaan Mulsa Terhadap Populasi Mikroorganisme dan Unsur Hara Pada Daerah Rhi zosfer Tanaman Kedelai (Glycine Max L.). E-Jurnal Agroekoteknologi Tropika Vol. 6, No. $1,41-51$

Ristiari, N. P. N., K. S. M. Julyasih, dan I. A. P. Suryanti. 2020. Isolasi Dan Identifikasi Jamur Mikroskopis Pada Rizosfer Tanaman Jeruk Siam (Citrus Nobilis Lour.) Di Kecamatan Kintamani, Bali. Jurnal Pendidikan Biologi Undiksha, Vol 6 No 1

Sahara, N. Wardah, dan Rahmawati. 2019. Populasi fungi dan bakteri tanah di hutan pegunungan dan dataran rendah di kawasan taman nasional Lore Lindu Sulawesi Tengah. J. ForestSains 16 (2),85 - 93

Solihin, M. A dan B. N. Fitriatin. 2017. Sebaran Mikroba Tanah pada Berbagai Jenis Penggunaan Lahan Di Kawasan Bandung Utara. Soilrens, Volume 15 No. 1, 38 - 45

Sulistiyono, F. D., dan S. Mahyuni. 2019. Isolasi Dan Identifikasi Jamur Endofit Pada Umbi Talas (Colocasia Esculenta (L.) Schoot). Jurnal Sains Natural Universitas Nusa Bangsa Vol. 9, No.2, $66-70$

Susilawati, Mustoyo, E. Budhisurya, R.C.W. Anggono, Bistok H. Simanjuntak. 2013. Analisis Kesuburan Tanah Dengan Indikator Mikroorganisme Tanah Pada Berbagai Sistem Penggunaan Lahan Di Plateau Dieng Soil Fertility Analysis With Soil Microorganism Indicator On Various Systems Of Land Use At Dieng
Plateau. AGRIC Vol.25, No. 1, Desember 2013: 64-72

Thuong T. T. Nguyen, Yu Jeong Jeon, Hye Yeon Mun, Jaeduk Goh, Namil Chung \& Hyang Burm Lee. 2020. Isolation and Characterization of Four Unrecorded Mucor Species in Korea, Mycobiology, 48:1, 29-36, DOI:

10.1080/12298093.2019.1703373

Widyati, E. 2013. pentingnya keragaman fungsional organisme tanah terhadap produktivitas lahan. Tekno Hutan Tanaman Vol. No. , 61 Maret 2013, $29-37$

Widawati S, Suliasih H.J.D, Latupapua, dan Sugiharto A. 2005. Biodiversity of Soil Microbes from Rhizosphere at Wamena Biological Garden (WBiG), Jayawijaya, Papua. Jurnal Biodiversitas, 6(1):6-11

Widyati, E. 2019. Intervensi Manusia Terhadap Komunitas Rhizosfir : Review. J. Manusia \& Lingkungan, 2019, 26(1):10-19

Yadav, N. V., P. Verma., B. Singh., V. S. Chauahan., A. Suman., and A. K. Saxena. 2017. Plant Growth Promoting Bacteria: Biodiversity and Multifunctional Attributes for Sustainable Agriculture. Adv Biotech \& Micro. 5(5): 555671. DOI: 10.19080/ AIBM.2017.05.5556671

Zainudin, dan R. Kesumaningwati. 2020. Peranan Kompos Pelepah Kelapa Sawit Dengan Bioaktivator Mol Pome Terhadap Peningkatan Sifat Biologi Tanah Sub Optimal. ZIRAA'AH, Volume 45 No 3, 360369 